資 料 溶けるということ ${ }_{532.73}^{U D C}$

How polymer dissolves.'

井 上幸 颜*

溶けるという現象は高分子でも低分でも本質的汇をそ えなに変らないので，理解しやすい低分子液体どうしの 混合と対比させながら高分子の溶解現象を解説する。

\section{1． 溶解を支配する因子}

1. 低分子の溶解 分子の大きさと形があまり相違 しない石油炭化水素どうしの混合では熱变化がなく，混 合はもっぱら濃度が均等になららとして互に拡散しあう （エントロピー增大）過程であり，2成分は任意の割合 に混合する。これが熱力学でいう理想混合で，同種分子 間㧍よび異種分子間の相互作用が同程度であると，たと 壳ば $\mathrm{A}$ 分子が $\mathrm{B}$ 分子で囲まれていても，他の $\mathrm{A}$ 分子で囲 まれていてもェネルギー的に同価で，混合による熱変化 がない $(\Delta H=0)$ 。しかし一般には吸熱 $(\Delta H>0)$ 的で 岕って， A-A 拈よび $\mathrm{B}-\mathrm{B}$ の引き合ら力は $\mathrm{A}-\mathrm{B}$ の引き 合う力より大きく, 溶解の障害になる。したがって, 混 ざろうとするエントロピー効果が，これに逆らうエネル ギー効果汇打ち勝つときだけ混合溶解が括こる。

エントロピーは無秩序の尺度であり，運動の自由度と 考えてもよい。分子過程は大きいエントロピーをもつ条 㭌の方へ進む。かかりやすくエントロピー効果を説明す f

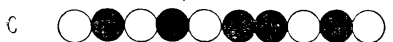

d

1
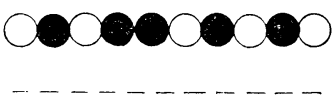

図 1 一次元モデル るため一次元モデル を考える。図１のよ 5 に 5 個ずつの白玉 と黒玉を 2 種の分子 とみて，これらを1 列に並べて混合状態 を表わしてみる。

（a）は混合前の状態，

(b) 以下は混合状態 に対応する。このような並べ方の数(確率)は252ある。 その5ち 1 つだけが混合前の状態であるから，これに比 ベ溶解状態は 251 倍の確率をもっておこる。すなわち, 分離しているより混ざり合っている方が安定である。エ ントロピーSは区別しラる状態の数 (確率) W の対数に

昭 35.11.30 受理

* 東京工業大学
比例する。

$S=k \ln W(k$ はボルツマン定数 $)$

この考えを一般化して， $n_{1}$ モルの溶媒に $n_{2}$ モルの溶 質が溶けるときのエントロピー変化を求めると

$$
\Delta S=-R\left(n_{1} \ln N_{1}+n_{2} \ln N_{2}\right)
$$

$$
N_{1}=n_{1} /\left(n_{1}+n_{2}\right), \quad N_{2}=n_{2} /\left(n_{1}+n_{2}\right): \text { モル分率 }
$$

2. 高分子の溶解 高分子は溶媒と同程度の大きさ の単位が $x$ 個連ってできた（近似的に重合度 $x$ ）分子鎖 であって，溶解のエントトピーは

$$
\begin{aligned}
& \Delta S=-R\left(n_{1} \ln \phi_{1}+n_{2} \ln \phi_{2}\right) \\
& \phi_{1}=\frac{n_{1}}{n_{1}+x n_{2}}, \phi_{2}=\frac{x n_{2}}{n_{1}+x n_{2}}: \text { 容積分率 }
\end{aligned}
$$

(1)，(2) の相違はモル分率の代りに容積分率をとっただ けであるが，これが重要な意義をもっている。もし両成 分の分子容が等しければ $(x=1)$ ，(2) は（1）と一致す るが，高分子の分子容は $x$ 倍大きいので，組成をモル分 率で表わせば，異常に大きな混合エントロピーを示すこ とになる。このことが高分子の浸透圧の異常性の原因で ある。浸透圧は溶質のモル分率に比例し, 分子量測定に 利用される。ところが組成を容積分率で表わすと，エン トロピーは単位容積中の分子の数に比例するから, 混合 のエントロピーは低分子の場合より小さくなる。たとえ ば分子容 $100 \mathrm{cc}$ の液体と $100,000 \mathrm{cc}$ の高分子を $1 \mathrm{cc}$ あ て常温で混合するときのエントロピー変化は $4.15 \mathrm{cal}$, 液体-液体系では $8.3 \mathrm{cal}$ である。さらに高分子-高分子 系では非常に小さくなり，0.008 cal である。これは重 要な意味をもち，高分子どうしの混合では原動力となる エントロピーが非常に小さいから，わずかでもエネルギ 一的な障害があると混合しないことになる。

\section{2. 溶 解 熱}

混合または溶解の過程に自由エネルギーの式

$$
\Delta F=\Delta H-T \Delta S \quad （ T \text { は絶対温度） }
$$

を適用すると，恒温，恒圧で溶解が進行するためには自 由エネルギーが減少 $(A F<0)$ しなければならない。 $\Delta H$ は混合で吸熱する場合は正 $(\Delta H>0)$ で，溶解の障壁を 表わし，エントロピーがそれ以上増せば $\Delta F$ は負になり 
溶解が進行する。 $\Delta S$ が大きいほど， $\Delta H$ が小さいほど 溶けやすい。

溶媒と溶質の $1 \mathrm{cc}$ あたりの凝集エネルギーを $e_{1}, e_{2}$, 溶媒と間の相互作用エネルギーを $e_{12}$ とすると, 混合の 正味のエネルギー変化は

$$
\Delta e=e_{1}+e_{2}-2 e_{12}
$$

ここに, $e_{12}$ は $e_{1}, e_{2}$ の幾何平均に等しいと仮定すると

$$
\begin{aligned}
& e_{12}=\sqrt{e_{1} e_{2}} \\
& \Delta e=\left(\sqrt{e_{1}}-\sqrt{e_{2}}\right)^{2}
\end{aligned}
$$

となる。混合による容積変化を無視すると, 混合エネル ギーは混合熱に等しい。モルあたり $\Delta E=\Delta H$ である。 $e=E / V(V$ は分子容 $)$ 分子凝集エネルギー密度といい, 便宜上平方根 $\delta=\sqrt{e}$ を溶解のパラメーターに使うこ とが多い。

\begin{tabular}{|c|c|c|c|}
\hline \multirow{3}{*}{\multicolumn{2}{|c|}{$\begin{array}{l}\text { 線状ジメチル } \\
\text { シロキサン } \\
(\mathrm{Si} 2 \sim 11) \quad 5.90 \sim 4.97 \\
\text { 脂肪族弗化炭化 } 5.5 \sim 6.2 \\
\text { 水䒺 }\end{array}$}} & $\begin{array}{l}\text { ジメチルサルフ } \\
\text { アイド }\end{array}$ & 9.4 \\
\hline & & 乳酸ブチル & 9.4 \\
\hline & & 5 塩化エタン & 9.4 \\
\hline \multicolumn{2}{|c|}{$\begin{array}{l}\text { 芳香族弗化炭化 } 7.5 \sim 8.2 \\
\text { 水素 }\end{array}$} & 酢酸メチル & 9.6 \\
\hline ネオペンタン & 6.3 & 塩化メチレン & 9.7 \\
\hline nーヘキサン & 7.3 & 2 塩化エチンン & 9.8 \\
\hline 1ーヘキセン & 7.4 & アノン & 9.9 \\
\hline エチルエーテル & 7.4 & セロソルブ & 9.9 \\
\hline ジイソブチレン & 7.7 & ジオキサン & 9.9 \\
\hline リン酸トリクレジル & 8.2 & 乳酸エチル & 10.0 \\
\hline サイクロヘキサン & 8.2 & エチラミン & 10.0 \\
\hline ターペンチン & 8.1 & アセトン & 10.0 \\
\hline ジペンテン & 8.5 & 酢 酸 & 10.1 \\
\hline 酢酸ブチル & 8.5 & 蟻酸メチル & 10.1 \\
\hline 四塩化炭素 & 8. 6 & 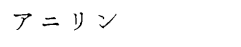 & 10.3 \\
\hline $\begin{array}{l}\text { セバシン酸 ジオ } \\
\text { クチル }\end{array}$ & 8.6 & メチルセロソルブ & 10.8 \\
\hline 酢酸セロソルブ & 8.7 & $\begin{array}{l}\text { エチレンオキサ } \\
\text { イド }\end{array}$ & 11.1 \\
\hline キシレン & 8.8 & $\begin{array}{l}\text { サイクロヘキサ } \\
\text { ノール }\end{array}$ & 11.4 \\
\hline トルエン & 8.9 & ブタノール & 11.4 \\
\hline 臭化ブロム & 8.95 & アセトアニリド & 11.7 \\
\hline 酢酸エチル & 9.1 & $\begin{array}{l}\text { ジメチルホルム } \\
\text { アミド }\end{array}$ & 12.1 \\
\hline $\begin{array}{l}\text { ダイアセトンア } \\
\text { ルコール }\end{array}$ & 9.2 & ニトロメタン & 12.4 \\
\hline $\begin{array}{l}\text { 酢酸メチルセロ } \\
\text { ソルブ }\end{array}$ & 9.2 & $\begin{array}{l}\text { ジメチル } \\
\text { ホスファイト }\end{array}$ & 12.5 \\
\hline ベンゼン & 9.2 & エタノール & 12.7 \\
\hline エチルメルカプタン & 9.25 & メタノール & 14.5 \\
\hline メチルエチルケトン & 9.3 & アンモ $=ア$ & 16.3 \\
\hline クロロベンゼン & 9.3 & 水 & 24.2 \\
\hline クロロホルム & 9.3 & & \\
\hline
\end{tabular}

$$
\Delta e=\left(\delta_{1}-\delta_{2}\right)^{2}
$$

\begin{tabular}{|c|c|}
\hline テフロン(ポリテトラフルオロエチレン) & 6.2 \\
\hline シリコンゴム(ポリジメチルシロキサン) & 7.3 \\
\hline ポリエチレン & 7.9 \\
\hline ポリイソブチレン, ブチルゴム & 7.8 \\
\hline 天 然 ゴム & 8.1 \\
\hline ポリブタジェン & 8.1 \\
\hline $\mathrm{GR}-\mathrm{S}(フ ゙$ タジェンースチレン $75 / 25)$ & 8.1 \\
\hline ポリスチレン & 8.56 \\
\hline ネオプレン(ポリクロロプレン) & 8.6 \\
\hline ブナ $\mathrm{N}($ ブタジェンーアクリロニトリル 75/25) & 8.9 \\
\hline ポリメチルメタクリレート & 9.08 \\
\hline ポリ酢酸ビニル & 9.4 \\
\hline ポリ塩化ビニル & 9.53 \\
\hline エチルセルロース & 10.3 \\
\hline ニトロセルロース & 10.56 \\
\hline ポリメタクリロニトリル & 10.7 \\
\hline ポリエチレンテレフタレート & 10.7 \\
\hline 2 酢酸セルロース & 10.9 \\
\hline エポキシ樹脂 & 10.9 \\
\hline ポリビニリデンクトライド & 12.2 \\
\hline ナイロン 66 & 13.6 \\
\hline ポリアクリロニトリル & 15.4 \\
\hline
\end{tabular}

表 1 液体の溶解性パラメーター． $\delta_{1},(\mathrm{cal} / \mathrm{cc})^{1 / 2}$
表 2 高分子の溶解性パラメーター, $\delta_{2},(\mathrm{cal} / \mathrm{cc})^{1 / 2}$

Ae は混りにくさの尺度で, 小さいほどよい。したがっ て溶質と溶媒の $\delta$ が似ているほど溶解の抵抗が小さい。

以上は低分子の理論であるが，高分子にもそのまま女 てはまる。相互作用エネルギー $\Delta e$ (正味の反発エネルギ 一）は高分子の重量（又溶積）に比例し単量体単位の $\delta$ を考えればよい。

熱力学的には多量の溶液に 1 モルの溶媒を加えたとき の自由エネルギー変化（希釈の自由エネルギー）に注目 して議論を進める。これは $\Delta F$ を $n_{1}$ で微分した值であ る。

$$
\begin{aligned}
\Delta S_{1}=\frac{\partial \Delta S}{\partial n_{1}} & =R\left\{\ln \left(1-\phi_{2}\right)+\left(1-\frac{1}{x}\right) \phi_{2}\right\} \\
& =R\left(\frac{\phi_{2}}{x}+\frac{\phi_{2}^{2}}{2}+\cdots \cdots\right)
\end{aligned}
$$

$$
\Delta \bar{H}_{1}=\frac{\partial \Delta H}{\Delta n_{1}}=B V_{1} \phi_{2}^{2}, \quad B=\left[\delta_{1}-\delta_{2}\right]^{2},
$$

$$
V_{1}=\text { 溶媒の分子容 }
$$

$$
\begin{gathered}
\Delta F_{1}=\frac{\partial \Delta F}{\partial n_{1}}=\Delta H_{1}-T \Delta S_{1} \\
=R T\left\{\left(\mu-\frac{1}{2}\right) \phi_{2}^{2}-\frac{\phi_{2}}{x}-\cdots \cdots\right\} \\
\mu=\frac{B V_{1}}{R T}
\end{gathered}
$$

$\mu$ を熱力学的相互作用係数という。溶解状態が安定であ るためには $\Delta F_{1} \leqq 0$ でなければならない。すると $\mu=$ 0.5 まではネエルギー障壁がエントロピー寄与で帳消に なって溶解状態が保たれる。ルが小さいほど良溶媒であ 
る。重合度 $x$ が非常に大きいと $\phi_{2} / x$ は消えるが， $x$ が 小さいとこのエントロピー寄与がきいて, さらにルが大 きくても溶ける。 と小さくなり，溶解範囲をなす。

\section{2 相 分 離}

溶解の限界条件は (9) を $\phi_{1}$ につて 1 回微分したも の，就よ゙ 2 回微分したものを 0 と预いて得られる。

$$
\mu^{c}=\frac{1}{2}\left[1+\frac{1}{\sqrt{x}}\right]^{2}=\frac{1}{2}+\frac{1}{\sqrt{ } x}
$$

\begin{tabular}{c|c|c|c|c|c}
\hline$x$ & $\infty$ & 1000 & 100 & 10 & 1 \\
\hline$\mu^{c}$ & 0.50 & 0.53 & 0.61 & 0.87 & 2.0 \\
\hline
\end{tabular}

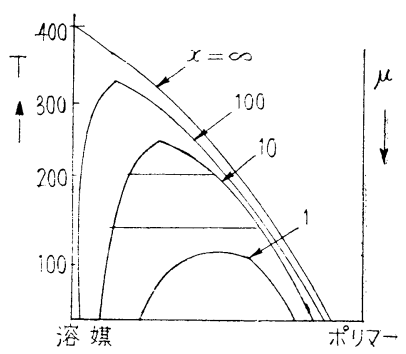

図 2

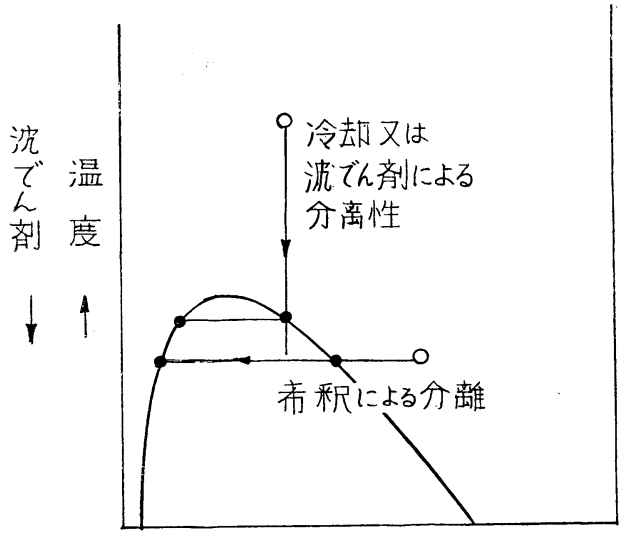

一溶質濃度

図 3

重合度が低くなるとエントロピー寄与が大きく，かなり エネルギー的に不利でも溶汁ることが知られる。(10),

(11)から図 2 の関係が得られる。曲線より下の部分は 2 相分離域で, 上は均一混合域である。

2 相分離の場合, 高分子は溶媒にわずかしか溶けない が, 高分子中の溶媒が溶け込むのは容易で, 液底体（沈 殿層）はある程度濃厚な溶液を形成する。したがって油 変性アルキドのミネラルスピリット溶液のような貧溶媒
系では濃厚溶液は安定でも, 希釈によって分離する, だ とえば表 3 のよな傾向が知られている。油長が短いほ ど低極性溶媒に溶计にくくなり, 高濃度で分離するよ5 になる。

表 3 大豆油变性アルキド樹脂の臨界濃度 ${ }^{1)}$ (重量\%), $25^{\circ} \mathrm{C}$

\begin{tabular}{|c|c|c|c|c|c|}
\hline & 媒* & $\begin{array}{c}\text { パラメ } \\
\text {-ター } \\
\delta \\
\end{array}$ & $\begin{array}{c}\text { 樹脂の和 } \\
\text { 短 }{ }^{\text {油 }} \\
(40)\end{array}$ & $\begin{array}{l}\text { 種類 (油土 } \\
\text { 中 油 } \\
(50)\end{array}$ & $\begin{array}{l}\text { 長, } \%) \\
{ }^{2} \text { 長 } \\
(60)^{\text {油 }}\end{array}$ \\
\hline (1) & $\begin{array}{l}\text { 無臭・ミネラル } \\
\text { スピリット }\end{array}$ & 7.1 & 52.1 & 11.3 & 混合 \\
\hline & ヘキサン & 7.3 & 42.6 & 3.9 & "1 \\
\hline (2) & $\begin{array}{l}\text { 低臭・ミネラル } \\
\text { スピリット }\end{array}$ & 7.6 & 25.3 & 混合 & "I \\
\hline (3) & ミネラルスピリット & 7.75 & 9.3 & "l & " \\
\hline \multicolumn{2}{|c|}{ メチルサイクロヘキサン } & 7.85 & 0.7 & "l & " \\
\hline
\end{tabular}

* 溶媒の組成 :

\begin{tabular}{|c|c|c|c|c|c|}
\hline 芳 & 香 族 & ナフテン & $\mid \begin{array}{ll} & 9 \\
\text { パラフ イン }\end{array}$ & $\begin{array}{l}7 \text { V } \\
7 \text { イ }\end{array}$ & $\begin{array}{l}\text { nーパラ } \\
\text { フイン }\end{array}$ \\
\hline (1) & - & - & 97 & 3 & - \\
\hline (2) & 2 & 29 & - & 1 & 68 \\
\hline (3) & 18 & 22 & - & $<1$ & 60 \\
\hline
\end{tabular}

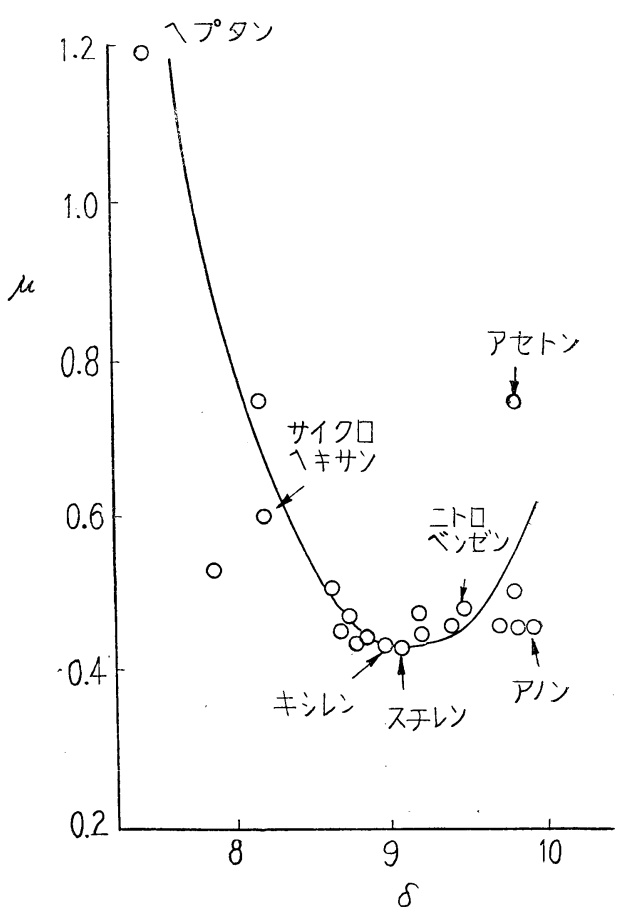

図 4 ポリスチレン $(\delta=8.56)$ の溶剤, 希釈剤 の $\mu \sim \delta$ 関係

図 4 はポリスチレン $(\delta=8.56)$ の溶剤, 希釈剤の $\mu$ $\delta$ 関係を示す。芳香族炭化水素やスチレンモノマーが最 
良の溶剤であるが $25^{\circ} \mathrm{C}$ に特ける $\mu$ が 0.4 以下にはなら ないから，むしろ貧溶媒である。ポリスチレンは極性基 をもたず，積極的な溶媒和は括こらない。このためポリ スチレンにはよい可塑剤がなく，また他の樹脂との相溶 性も極端に悪い。スチレン化アルキド樹脂が相溶性の悪 いことも同じ理由によるものであろう。

\section{4. 多成 分 系}

混合溶媒および混合樹脂系の混合の自由エネルギーの 一般式はつぎのようになる。

$$
\begin{aligned}
& \frac{\Delta F}{R T}=\sum n_{i} \ln \phi_{i}+\sum_{i<j} n_{i} \phi_{j} \mu_{i j} \\
& \phi_{i}=x_{i} n_{i} / \sum x n, \quad \mu_{i j}=\mu_{j i} x_{i} / x_{j} \\
& n_{i}=\phi_{i} / x_{i}, \quad N=\sum x_{i} n_{i}
\end{aligned}
$$

成分 $n_{i}$ の希积の部分モル自由エネルギーは上式を $n_{i}$ 関して偏微分して得られる。しかし，3成分系でも， 古でに相平衡を基本的に解くには数学的困難を伴なうの で， $\phi, x, \mu$ に代表的数值を入れて例解を求めて実験と 対比してみるほかはない。つぎに重要な結果だけを紹介

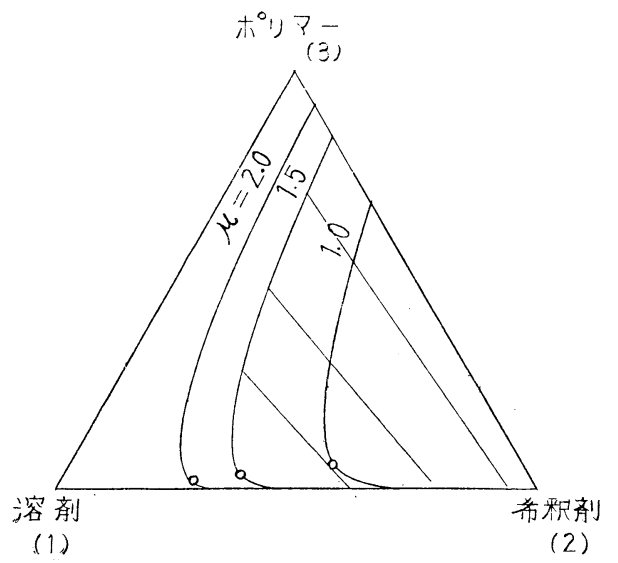

㳗 5 溶剂・希橎剂ポリマー系つ相平衡モデル

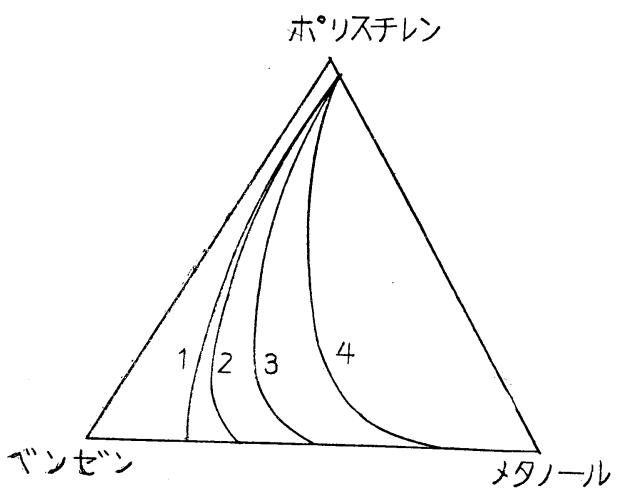

図 6 ポリスチレン・ベンゼン・メタノール系の相図
する。図 5 は希釈剤 (1)一溶剤 (2)一ポリマー (3) 系に 执いて, $\mu_{12}=\mu_{13}=\mu, \mu_{23}=0, x=100$ と沶いて $\mu$ を変 化させた場合の相図である。一般的傾向は図 6 のポリス チレン・ベンゼン・メタノール系とよく似ている。ポリ マーの $\delta$ が 2 つ液体のそれの中間に女る場合には，単 独では溶解力を示さなくてもある組成範团の混液が溶济 となる場合が知られている。図 7 は $x_{1}=x_{2}=1, x_{3}=\infty$, $\mu_{12}=2, \mu_{13}=\mu_{23}=0.75$ とした場合の相図で, 結線は平衡 2 相の組成を示す。対応する例はエチルアルコール(1). クロロホルム (2)・酢酸セルロース (3) 系で, $x=953$ の 場合にアルコール濃度 6〜 47\% で溶解力がある。そして $x=953, \mu_{12}=1.10, \mu_{13}=1.00, \mu_{23}=0.56$ と打いた相 図は図 8 のようになり，臨界点（図の○印）の組成は穾 測値とよく一致する。

つぎに塗料に重要な混合ポリマー系のモデルとしてポ リマー (1)・ポリマー (2)・溶剤 (3) 系を考学る。簡単

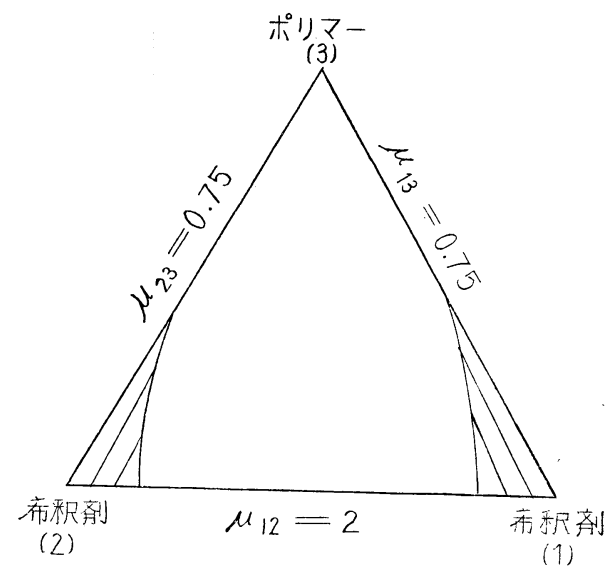

図 7 希釈剤の混液が溶剤となる場合の相図

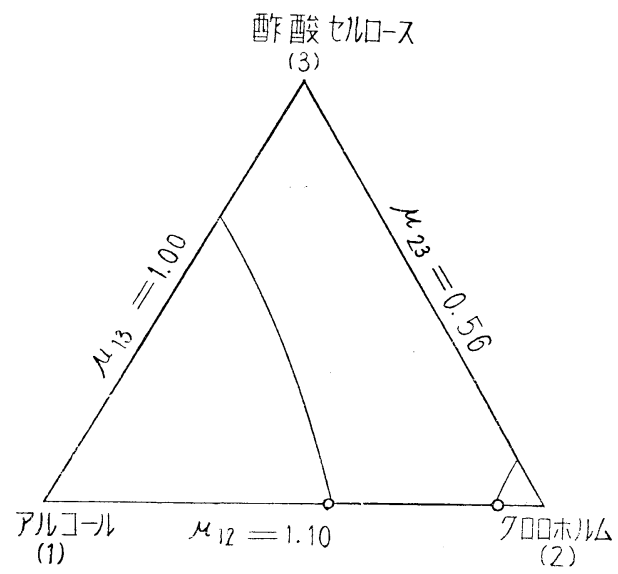

図 8 酢酸セルロース・クロロホルム・アルコ 一ル系の相図 


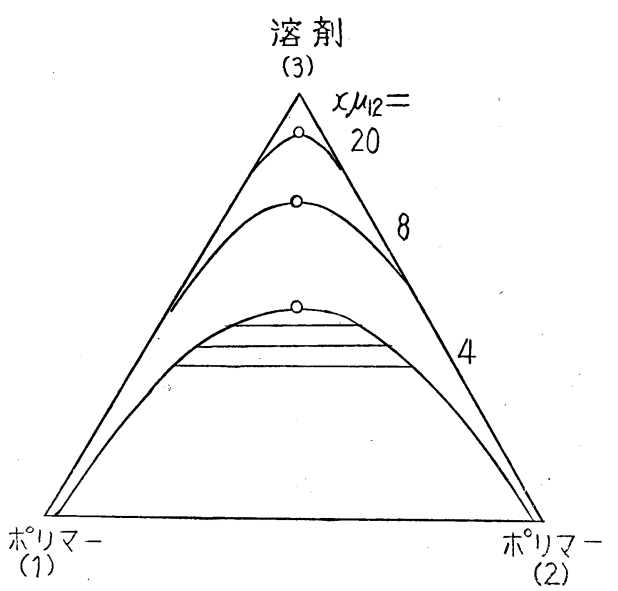

図 92 種ポリマーが共通溶剤に溶ける場合の相図

$$
x_{1}=x_{2}=100, x_{3}=1
$$

のため $x_{1}=x_{2}=x, x_{3}=1, \mu_{13}=\mu_{23}=\mu$ と打くと, 平衡 2 相に和ける $\phi か ゙$ 等しくなり, 解法は簡単で, つぎの臨 界条件が得られる。

$$
\left.\begin{array}{l}
x \mu_{12}^{c}\left(1-\phi_{3}\right)=2 \\
\phi_{1}^{c}=\phi_{2}^{c}=\frac{1}{x \mu_{12}^{c}}=\frac{1-\phi_{3}}{2}
\end{array}\right\}
$$

$x=100$ の場合の $\mu_{12} \sim \phi_{3}$ 関係は次表のようになり，図 9 はこの場合の相図を示す。ポリマー 1,2 に関し対称性

\begin{tabular}{c|c|c|c}
\hline$x \mu_{12}$ & 4 & 8 & 20 \\
\hline$\mu_{12}^{\prime *}$ & 0.04 & 0.08 & 0.20 \\
$\phi_{3}^{c}$ & 0.5 & 0.75 & 0.9 \\
\hline
\end{tabular}

* 添字 c は臨界値を表わす

のため結線は水平になる。

溶剂を含まない固相に括けるポリマー 2 成分系では相 分離の臨界条件は

$$
\mu^{c}=\frac{1}{2}\left(1 / \sqrt{x_{1}}+1 / \sqrt{x_{2}}\right)^{2}
$$

で与えられ，次表のよ5に $x$ の増大により均一混合に許 されるルの上限が急減することが知られる。

\begin{tabular}{ll|c|c|c|c}
\hline$x_{1}$ & 1 & 10 & 100 & 10 & 1000 \\
$x_{2}$ & 1 & 10 & 100 & 1000 & 1000 \\
\hline$\mu^{c}$ & 2 & 0.2 & 0.02 & 0.05 & 0.002 \\
\hline
\end{tabular}

$x_{1}=x_{2}=100$ の場合を前の表と比べてわかるように，溶 剤の存在によって許される $\mu^{c}$ の值は大きくなるが，共 通溶剤に溶け, 溶液としては混合しても乾燥とともに分 離する場合があっても不思議ではない。ポリスチレン $(\delta=8.56)$ とポリメチルメタクリレート (9.08) のキシ レン溶液は脱混合し, 均一相を作るのは $85^{\circ} \mathrm{C}$ 以上であ
る。

以上のことから，ポリマーどおしはむしろ相溶しない のが原則であり，相溶する場合には成分間に特別の親和 性があって特定の基の間に強溶媒和 $(\Delta H<0, \mu<0)$ の おこることが考光られる。

\section{5. 溶 媒和}

前章までの理論は厳密には非極性溶媒に非極性溶質ぶ 溶ける場合にだけ適用され，ある程度玉で極性溶媒・溶 質系へも抁張できる。しかし溶質・溶媒間に水素結合な どの特別の相互作用のおこる場合は別汇考党なければな らない。溶媒和が怙こると $\Delta H<0$ (発熱)で, $e_{12}>\sqrt{ } \bar{e}_{1} e_{2}$ となり無限に溶解する。 $\delta$ の相違が大きくても溶ける。 ニトロセルロース $(\delta=10.56)$ が酢酸ブチル $(\delta=8.5)$ その他の極性溶媒に溶ける場合がこれに相当する。この 場合にはニトロセルロースの $\mathrm{ONO}_{2}$ 基にエステル基なぞ

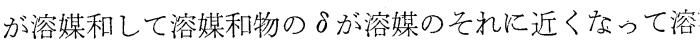
けると考觉られる。どのような組合せのとき溶媒和が等 こるかはすずかしい問題であるが，電子供与性の基と電 子受容性の基の間に括こると考えられる。

電子受容能の順位

$$
\begin{aligned}
& =\mathrm{CHCl}<-\mathrm{CHCl}_{2}<=\mathrm{CHONO}_{2}<=\mathrm{CHNO}_{2}< \\
& =\mathrm{CHCN}<-\mathrm{C}_{6} \mathrm{H}_{4} \mathrm{OH}<-\mathrm{COOH}<-\mathrm{SO}_{2} \mathrm{H}
\end{aligned}
$$

電子供与能

$$
\begin{aligned}
& -\mathrm{CH}_{2} \mathrm{OCH}_{2}-<-\mathrm{CH}_{2} \mathrm{OCOCH} \mathrm{CH}_{2}-<-\mathrm{CH}_{2} \mathrm{COCH}_{2} \\
& -<\equiv \mathrm{PO}_{4}<-\mathrm{CONH}-<-\mathrm{CON}\left(\mathrm{CH}_{3}\right)_{2}<-\mathrm{C}_{6} \mathrm{H}_{4} \mathrm{NH}_{2} \\
& <-\mathrm{CH}_{2} \mathrm{NH}_{2}
\end{aligned}
$$

これらの中には再性の基もある。酢酸エステルのカルボ ニル基-CO-は供与性であるが， $\mathrm{CH}_{3}$ の 1 つの $\mathrm{H}$ は弱い 受容性を示す。ニトロ基, 硝酸基は受容性であるが，幾: 分供与性を示す。アミド基の CO は供与性であり, NR ついているHは受容性である。ニトロセルロース（受容 性）はケトン，エステル，リン酸エステルなどの供与性 溶媒に，三酢酸セルロース（供与性）はメチレンクロラ イド，クロロホルムなどの受容性溶媒に溶ける。両性基: をもつ高分子はどちらの形の溶媒にも溶ける。

\section{6. 希 㯊 価}

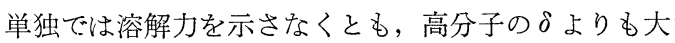

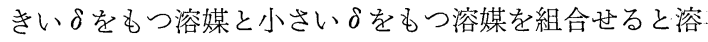
解力を発揮する場合がある。少なくとも肴釈能は増大す る。溶剤と沈殿剤の組合せにおいて, 高分子に対し両者 の $\delta$ がとに大きいか, 小さいときは希釈価は溶解力の 指標になる。

一定濃度 $C_{0}$ の樹脂溶液一定量をとり, 沈殿剤で滴定 


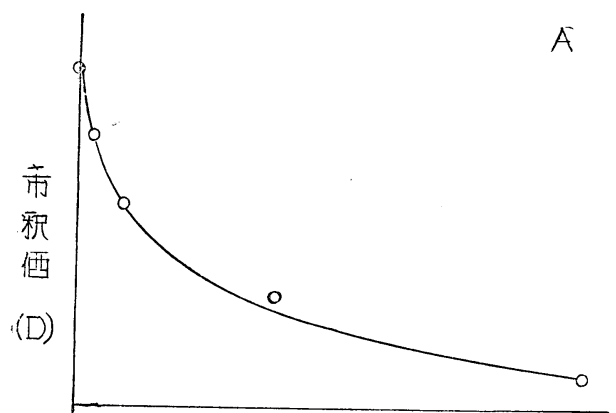

初濃度C。

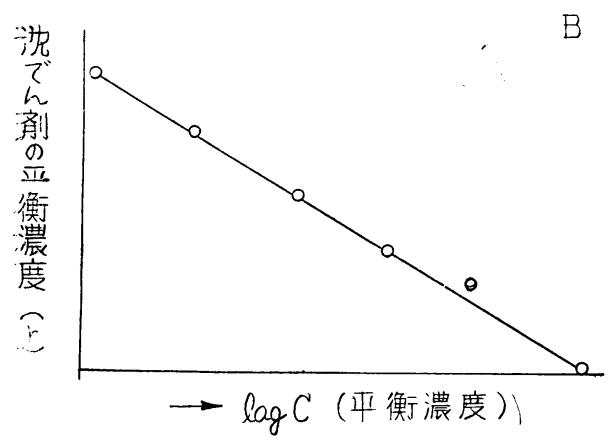

図 10 希䣋価の説明図

し，溶液が濁りはじめるまでに加えられた沈澱剤の量 $D$ を比較する。ところが $D$ は $C_{0}$ 飞よって大きく変動す る。溶解平衡では $C_{0}$ でなく, 最終濃度 $C$ をとるべきで, 希釈価も $D$ でなく最終混液中の沈澱剂濃度 $\gamma$ で比較し

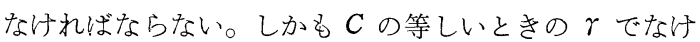

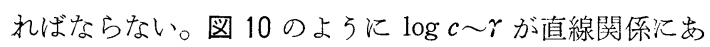
ろ。

$$
\begin{aligned}
\ln c=a- & b \gamma \\
& (a, b \text { は定数 })
\end{aligned}
$$

重合度 $x$ が大きくなると溶けにくくなり，この関係は

$$
r=a^{\prime}+b^{\prime} / x
$$

で表わされ，結局

$$
\ln c=-P(A+B r) / R T
$$

となる。これは Schulz の与えた実験式である。

$P(A+B r)$ は溶解状態と非溶解状態のエネルギー差で, $\Delta e=A+B r$ が正の小さな值であれば, エントロピー寄 与があろので溶解し, 負 (溶媒和) であれば無限溶解 する。

$c \sim \gamma$ 関係と $c \sim \mu$ 関係を対比すると図11のようにな る。相平衡曲線は極大曲線であるから, 滴定後の溶質濃 度 $C$ が極大位置より高濃度側にくるか, 低濃度側にくる

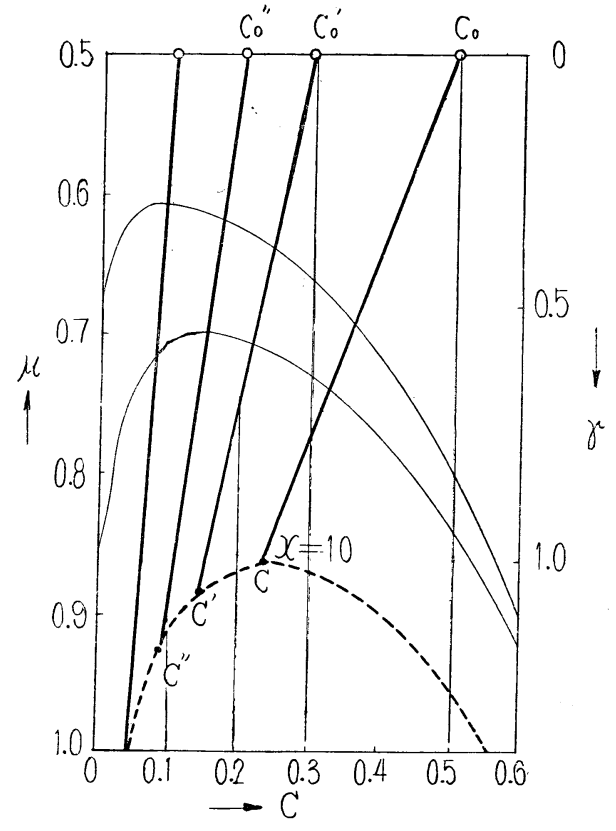

困 11 希釈価の説明図

かで希釈価 $D$ の濃度依存性が違ってくる。

\section{7. 希釈価と粘度}

文献にはしばしば実用本位に溶液粘度 $\eta$ だけを問題に しているが，溶媒自体の粘度 $\eta_{0}$ に対する比粘度 $\eta_{\gamma}=\eta /$ $\eta_{0}$ で比較すれば溶解性との関係の考察に役立つであろ う。希薄溶液では溶解状態がよいほど溶けているポリマ 一分子は伸びて拡がった状態にあり $\eta_{\gamma}$ なたは極限粘度 $[\eta]=\left(\eta_{s p} / c\right)_{c \rightarrow 0}, \quad \eta_{s p}=\eta_{\gamma}-1$, が大きい。しかし濃度が 大きくなると, 溶解状態が悪く縮まる傾向のあるポリマ

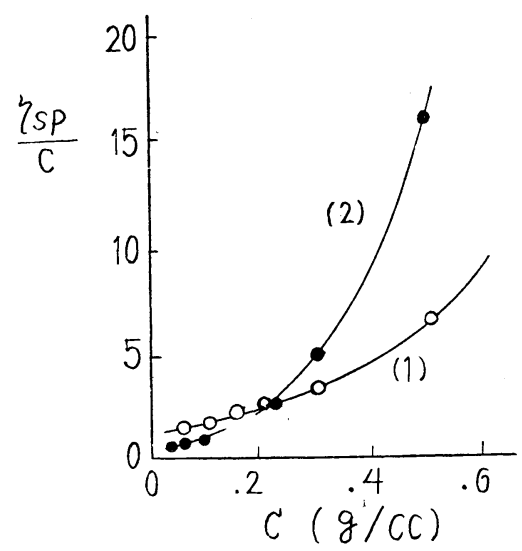

図 12 VYHH の粘度濃度関係

(1) サイクロヘキサノン（良溶媒）

(2) ブタノン（貧溶媒） 
一の分子鎮はからみ合って急に粘度を増す(図12参照)。 ニトロセルロースの希薄溶液 $(c<0.5 \%)$ で調ベられ

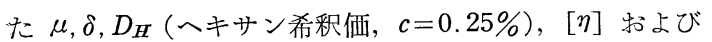
Huggins の係数 $k^{\prime}$

$$
\frac{\eta_{s p}}{c}=[\eta]+k^{\prime}[\eta]^{2} c
$$

について表 4 の結果 ${ }^{2}$ が報告されている。良溶媒ほど $[\eta]$ 婊 4 ニトロセルロース*希薄溶液の性質

\begin{tabular}{|c|c|c|c|c|c|}
\hline 媒 & $\mu$ & $\delta$ & $D_{I}$ & {$[\eta]$} & $k^{\prime}$ \\
\hline$ア セ ト ン$ & 0.27 & 9.760 & 0.803 & 2.79 & 0.49 \\
\hline メチルエチルケトン & 0.27 & 9.151 & 1.01 & 3. 29 & 0.40 \\
\hline メチルnープロピルケトン & 0.15 & 8.841 & 1.17 & 3.56 & 0.44 \\
\hline メチルnーアミルケトン & 0.02 & 8.451 & 1.44 & 3.82 & 0.41 \\
\hline メチルnーヘキシルケトン & 0.16 & 8.351 & 1. 42 & 3.49 & 0.30 \\
\hline 酢 酸メチル & 0.30 & 9.55 & 0.78 & 3.30 & 0.54 \\
\hline 酢 酸 エチル & 0.22 & 9.05 & 1.20 & 4.11 & 0.35 \\
\hline$n$-酢酸プロピル & 0.13 & 8.75 & 1. 40 & 4.23 & 0.38 \\
\hline$n$-酢 酸 ブチル & 0.015 & 8.53 & 1.56 & 4.20 & 0.43 \\
\hline$n$-酢酸 アミル & 0,02 & 8.45 & 1.49 & 4. 21 & 0.35 \\
\hline
\end{tabular}

* $N=12.2 \%, \bar{M}_{n}$ (数平均分子量 $)=90,000$

が大きく $k^{\prime}$ が小さいのが通則である。表 4 によると， 洞族列の溶媒では分子容が大きくなると $\mu$ が小さくな り， $[\eta], D_{H}$ を増し， $k^{\prime}$ を減少しているから，溶解状態 がよくなることが知られる。もっともケトン類ではメチ ル $n$-アミル, 酢酸エステル類では $n$-ブチルが最大溶解 力を示すようである。

\section{8. 溶解のヒステレシス}

ジニトロセルロース，第二次酢酸セルロース拉よびポ き塩化ビニルなどはX線的には明らかな結晶性を示さな
いが，これは結晶化度が低く，かつクリスタリットが非 常に小さいためである。ところがこれらは溶解性に関し ては明らかに結晶性ポリマーの特性を示し, 分別溶解と 分別沈殿とでは溶解に必要な溶剂量を異にし, 溶解のヒ ステレシスが認められる。これらの場合, 溶解にはなず 溶媒和によって結晶が融解し，ついで無定形溶媒和物が 溶媒中に拡散してゆく。そして溶解の障壁が前者にある ので, はじめ強い溶剤に溶かした後希釈すれば多量の希 釈剂を加兄ても沈殿しないが（分別沈殿），最初から溶 剂・希釈剂混液で溶かそうとすると（分別溶解）分別沈 殿の場合より溶剂濃度の高い混液を必要とする。

実際のラッカーではある程度溶解力に余裕のある混合 溶媒が用いられるから, 溶剤と希釈剂のいずれを先に加 えても終局の溶解状態は変らない。しかし，たとえば硝 化綿を混合溶媒中に投入すると，直ちに表面が膠化し， 内部が未湿潤のまま塊状となって, 溶媒の浸透が著しく 困難となり，溶解に長時間を要する。これに反して，ま ず希釈剂を加えて湿らせ，十分膨潤させた後溶剤成分を 加とろと溶解は非常に早く終る。これは現場常識であ る。な拉，一見溶けたようにみ兄ても，分子状に溶解す るまでには時間を要するから，経時的に粘度が下って一 昼夜くらいで平衡に達することが多い。貧溶媒系による ときは加温溶解するのが無難である。

\section{文献}

1) W.W. Reynolds : Off. Digest, 29, 966(1957).

2) W.R.Moore et. al. : J.Polymer Sci., 23, 23 (1957).

\section{参 考 書}

H. Tompa "Polymer Solutions", Butterworths Sci. Publ. (London) 1956. 